\title{
Single Tooth Prosthetic Restoration Through Surgical Crown Lengthening, Conservative Therapies and CAD-CAM Milled Restoration in Lithium-Disilicate: A Case Report
}

\section{Protetička restauracija pojedinačnog zuba kirurškim produljenjem krune, konzervativnom terapijom i litijevim disilikatnim nadomjestkom proizvedenim CAD-CAM tehnologijom: prikaz slučaja}

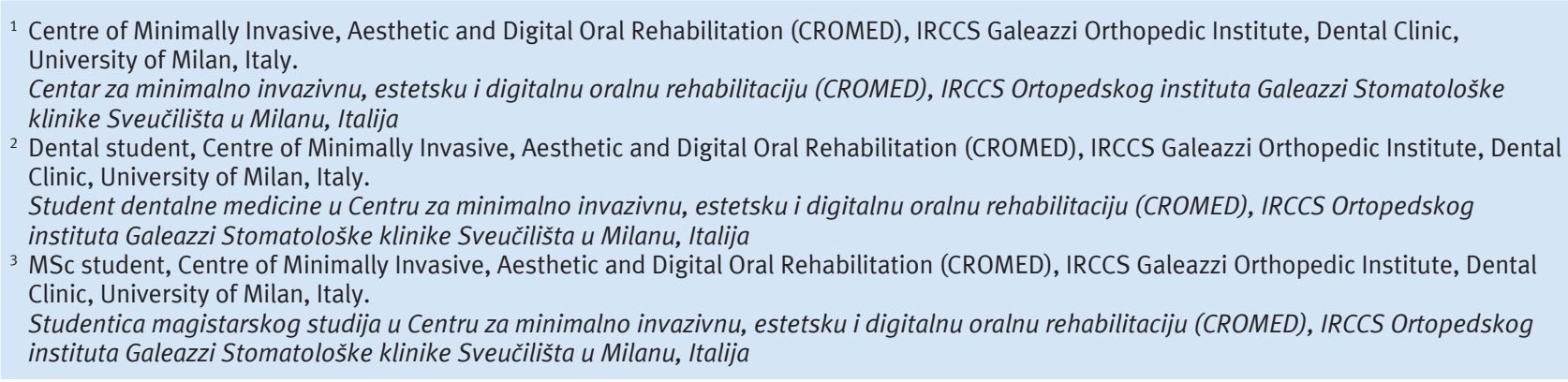

Abstract

Objective. The restorative treatment of a decayed, non-vital upper premolar often requires an interdisciplinary approach. Esthetics and the entity of the masticatory loads are usually affecting the choice of procedures and materials. A conservative treatment in a case with esthetic needs and functional requirements is investigated in this case report. Materials and methods. A case of a 45- yearold woman with a severely decayed upper premolar is presented. The tooth has been previously treated in an emergency department with a provisional endodontic medication, but a further treatment has been then performed. The tooth was painful at the moment of the visit and the carious lesion appeared to invade the subgingival level. A surgical-conservative approach has been selected involving crown lengthening, endodontic treatment and a prosthetic crown with a monolithic Lithium-Silicate. Results. The rehabilitative process required 3 months, including maturation times after surgery and the placement of the provisional crown. The patient claimed to be both esthetically and functionally satisfied with the restoration. Conclusion. A conservative treatment of a severely involved tooth requires a critical evaluation of the remaining structures and a precise selection of the restorative materials. A monolithic crown could represent an ideal solution for restoring an upper premolar requiring esthetics and solid function, but the choice of a high translucent, easily polishable and possibly even chair-side prosthetic material might be an appreciable added value for clinicians.
Received: August 30, 2019

Accepted: December 1, 2019

Address for correspondence Matteo Basso

University of Milan

Dental clinic

CROMED

Milan, Italy

clinic@matteobasso.it

Key words

Bicuspid; Crown Lengthening; Crowns

\section{Introduction}

The restoration of serious tooth decay often requires an interdisciplinary approach. For example, the dentist can be required to restore esthetics and function of an upper premolar, where the esthetics and the entity of the masticatory loads are often affecting the choice of procedures and materials and even general prognosis of the tooth.

In fact, there are lots of influences to consider in this case: position and size of the cavity; requirement of endodontic
Uvod

Restauracija znatno oštećenog zuba često zahtijeva interdisciplinarni pristup. Na primjer, od kliničara se može zahtijevati rekonstrukcija estetike i funkcije gornjeg pretkutnjaka, no pritom estetski zahtjevi i žvačno opterećenje često utječu na izbor postupaka i materijala, pa čak i na opću prognozu zuba.

U ovom slučaju nekoliko je čimbenika o kojima treba voditi računa - to su položaj i veličina kaviteta, potreba za en- 
treatment; size of the future restoration; requirement of endodontic post; requirement of prosthetic rehabilitation; position of the bone crest; length of the root; status of teeth adjacent to a single-tooth; oral hygiene and the patient's compliance; cost.

In many cases, when the rehabilitation plan of a premolar includes different and complex treatments such as endodontic treatments, posts or extensive restorations, the dentist tends to choose an implant-supported prosthetic rehabilitation, because the costs of the above mentioned conservative treatments could be similar to those of the implant-supported ones, but the overall prognosis of a tooth-supported prosthesis may be, in the mind of professionals and in the literature, lower than that of a crown over implant $(1,2)$. The prognosis of both rehabilitations is strongly affected by different factors such as the surgeon, his skills, used materials, the patient's habits, and a definite conclusion concerning the best solution to the problem; either endodontic treatment or implant-supported therapy, still cannot be reached (3).

However, the rehabilitative treatment of a natural tooth is usually faster and the conservative treatment represents, biologically and when possible, always the best choice. In this case, the right selection of prosthetic materials could be decisive.

\section{Case report}

A 45- year- old woman patient, B.S., visited the dental clinic of the IRCCS Istituto Ortopedico Galeazzi (Milan, Italy) reporting the pain in her upper left dental arch. When her medical history was taken, she stated that she was not a smoker, was not affected by any chronic disease and was in good health.

During the clinical oral examination, she did not exhibit any mucosal lesions, she presented a good level of oral hygiene but there were numerous incongruous restorations, especially a temporary-like restoration on tooth \#25.

This tooth was not stimulated with the cold test and the radiographic image revealed an incomplete endodontic treatment (Figures 1-2). The tooth seemed to present a suitable root length for a conservative restoration, but the apical position of the carious lesion and the proximity of the interdental bone ridge did not allow a correct rehabilitation with prosthetic crown, respecting the biological width (4).

Considering the patient's factors (e.g. age, level of oral hygiene, absence of smoking or other risk factors) and status of the tooth (e.g. length of the root, endodontic access, periodontal status), therefore, it was communicated to the patient that the treatment plan would include:

- Pre-endodontic restoration in a suitable material to obtain a complete sealing even on the subgingival dentin.

- Root canal therapy of the tooth.

- Surgical crown lengthening for an optimal adhesion $(5,6)$.

- Permanent restoration using a composite material with the insertion of an endodontic fiber post $(7,8,9)$.

- Prosthetic preparation of the tooth with the BOPT technique and the placement of a temporary crown $(10,11)$.

- Placement of the definitive crown in a material that will be suitable for a new clinical situation dodontskim liječenjem, veličina buduće restauracije, potreba za intrakanalnom nadogradnjom i protetičkom rehabilitacijom, položaj koštanoga grebena, duljina korijena, stanje susjednih zuba, oralna higijena i pacijentova suradnja te cijena.

Često, kada plan za rehabilitaciju pretkutnjaka uključuje različite i složene zahvate poput endodontskog liječenja, nadogradnji ili velikih restauracija, kliničar odabire implantoprotetičko liječenje jer troškovi konzervativne terapije mogu biti slični kao i oni za implantate, ali ukupna prognoza nadomjestka na prirodnom zubu može, prema dijelu literature, biti nepovoljnija u odnosu prema implantoprotetičkim nadomjestcima $(1,2)$. Na prognozu u oba slučaja snažno utječu različiti čimbenici, uglavnom kliničar i njegova vještina, zatim korišteni materijali i pacijentove navike, pa se ne može donijeti konačni zaključak o tome koje je rješenje najbolje - terapija nadomjestkom na prirodnom zubu ili implantatu (3).

No terapijski koncepti koji uključuju prirodne zube obično su brži i konzervativno liječenje najbolji je izbor kad god je to moguće, a u ovom slučaju mogao bi biti presudan pravi izbor protetičkoga materijala.

\section{Prikaz slučaja}

Pacijentica u dobi od 45 godina - B. S., došla je u stomatološku kliniku IRCCS Ortopedskoga instituta Gleazzi (Milano, Italija) zbog bolova lijevo u gornjem zubnom luku. Tijekom anamneze navela je da ne puši, nema ni jednu kroničnu bolest i dobrog je općega zdravlja.

Tijekom kliničkoga oralnog pregleda nisu pronađena oštećenja sluznice, razina oralne higijene bila je dobra, ali s mnogo insuficijentnih restauracija i privremenim ispunom na zubu 25.

Taj zub nije reagirao na test hladnoćom, a rendgenska snimka otkrila je nepotpuno endodontsko liječenje (slike 1. i 2.). Čini se da je imao odgovarajuću duljinu korijena za konzervativno liječenje, ali, zbog potrebne biološke širine, apikalni položaj karijesne lezije i blizina interdentalnoga koštanog grebena nisu dopuštali ispravnu rehabilitaciju protetičkom krunicom (4).

Uzimajući u obzir čimbenike povezane s pacijentom (npr. dob, razinu oralne higijene, pušenje ili druge rizične čimbenike) i status zuba (npr. duljina korijena, endodontski pristupni otvor, parodontološki status), pacijentici je rečeno da će plan liječenja uključivati:

- predendodontsku restauraciju odgovarajućim materijalom kako bi se postiglo potpuno brtvljenje, čak i na subgingivnom dentinu

- endodontsko liječenje zuba

- kirurško produljenje krune kako bi se izložio dio zdravog dentina za optimalnu adheziju $(5,6)$

- trajnu opskrbu kompozitnim materijalom, uz korišstenje kompozitne nadogradnje ojačane vlaknima $(7,8,9)$

- protetičku preparaciju zuba BOPT tehnikom i postavljanje privremene krunice $(10,11)$

- izradu trajne krunice u materijalu koji će odgovarati novoj kliničkoj situaciji. 


\section{Operational phases}

The first step consisted of the removal of the decayed tissue of the distal face of the tooth 25 in its coronal portion and in the first third of the root.

The cervical limit of the decay has been exposed, then the wall has been reconstructed with a glass ionomer material (EQUIA Forte ${ }^{\mathrm{TM}}$, GC Corp, Tokyo, Japan) coated with the light curable EQUIA Forte Coat ${ }^{\mathrm{TM}}$ to obtain a more resistant material even in case of occlusal loads (12-14). Glass ionomer material has been chosen because the apical edge of the tooth cavity was under the gingival margin; therefore, it was impossible to obtain a correct isolation for a composite restoration. It has been confirmed that the glass ionomer materials can tolerate acid and humid environments more than composites (12-14).

The EQUIA Forte was selected among different glass ionomer cements since it has been reported in the literature that it has better long-term results (12-16).

After that, the endodontic treatment of the tooth has been performed. The tooth had only one root canal, processed with a hand file READY STEEL K-File ${ }^{\mathrm{Tm}}$ (Dentsply Sirona, Italy) and, for the shaping and refinement, with mechanical file PROTAPER GOLD ${ }^{\mathrm{TM}}$ (Dentsply Sirona, Italy) at a working length of $20 \mathrm{~mm}$.

The sealing of the canal has been performed with a Thermafil ${ }^{\text {TN }}$ cone (Dentsply Sirona, Italy) with an apical diameter of $0.30 \mathrm{~mm}$. (Figure 3)

The third step of the treatment consisted of the crown lengthening, necessary to expose an adequate part of the root, to obtain, after healing, the correct adhesion of the composite for the pre-prosthetic restoration and the successive prosthetic rehabilitation.

After the surgical flap elevation of the tissue and the bone remodeling, the flap was repositioned apically and sutured with vertical mattress suture anchored in the periosteum. The suture was removed after 7 days.

During the fourth phase, after waiting for a postsurgical healing time of 4 weeks necessary for the correct maturation of the tissues, the glass ionomer and coronal part of the endodontic material has been removed with the Gates Glidden ${ }^{\text {TM }}$ cutters (Dentsply Sirona, Italy) with 01-02-03 size, it has been inserted a glass fiber post with a medium size truncated cone form, Anatomical Post (DENTALICA, Italy), fixed by a self-adhesive dual-cure cement (GCem LinkAce ${ }^{\text {TM }}$ translucent, GC Corp, Tokyo, Japan). The permanent composite restoration was completed with the Gaenial Posterior ${ }^{\text {rm }}$ shade A3 composite (GC Corp, Tokyo, Japan) bonded with its respective self-etch adhesive (Gaenial Bond $\left({ }^{\mathrm{rx}}\right)$ ).

After the restoration, the tooth was prepared with the B.O.P.T technique and a provisional crown in PMMA, obtained with an optical scan done before the preparation of the element with a AADVA IOS100 scanner (GC Corp, Tokyo, Japan), was placed. During this phase the old restorations of the teeth 24 and 26 were replaced (Figures 4-5), (10, 11).

After another 4 weeks, the refinement of the prosthetic abutment was performed and the definitive dental impression with Polyvinylsiloxan-Ether (PVS-E, Exa'Lence ${ }^{\mathrm{TM}}$, GC Corp., Tokyo, Japan) (figure 6) was taken. The dental im-

\section{Klinički postupci}

Prvi potez sastoji se u uklanjanju karioznog tkiva s distalne strane zuba 25 u njegovu koronarnom dijelu i u prvoj trećini korijena.

Otkrivena je cervikalna granica karijesa, a zatim je stijenka rekonstruirana stakleno-ionomernim cementom (EQUIA Forte $^{\mathrm{TM}}$, GC Corp, Tokio, Japan) presvučenim svjetlosno polimerizirajućim premazom EQUIA Forte Coat ${ }^{\mathrm{TM}}$ kako bi se dobio otporniji materijal čak i u slučaju jačeg okluzalnog opterećenja $(12-14)$. Odabran je stakleno-ionomerni materijal jer je apikalni rub kaviteta bio smješten subgingivno, pa je bilo nemoguće postići apsolutnu izolaciju za kompozitnu restauraciju - sada je sigurno da stakleno-ionomerni materijali mogu podnijeti kiselo i vlažno okružje bolje od kompozita $(12-14)$.

Između različitih stakleno-ionomernih cemenata odabran je EQUIA Forte jer je prema literaturi pokazao bolje dugoročne rezultate $(12-16)$.

Nakon toga provedeno je endodontsko liječenje. Zub je imao samo jedan korijenski kanal koji je obrađen ručnim instrumentom READY STEEL K-File ${ }^{\text {Tx }}$ (Dentsply Sirona, Italija), a za oblikovanje i završnu obradu korišten je PROTAPER GOLD ${ }^{\mathrm{TM}}$ (Dentsply Sirona, Italija) na radnoj duljini od $20 \mathrm{~mm}$.

Brtvljenje kanala postignuto je štapićem Thermafil ${ }^{\mathrm{TM}}$ (Dentsply Sirona, Italija) apikalnog promjera od $0,30 \mathrm{~mm}$ (slika 3.)

Treći potez u liječenju sastojao se u nužnom produljenju kliničke krune kako bi se izložio odgovarajući dio korijena da bi se postigla adekvatna adhezija kompozita za pretprotetičku terapiju i protetičku rehabilitaciju.

Nakon kirurškog podizanja režnja i remodeliranja kosti, režanj je pomaknut apikalno i učvršćen vertikalnim madračnim šavom usidrenim u periostu. Šav je uklonjen nakon 7 dana.

Tijekom četvrte faze, nakon čekanja poslijekirurškog razdoblja cijeljenja od četiri tjedna potrebnog za pravilno sazrijevanje tkiva, stakleno-ionomerni cement i koronalni dio endodontskog punila uklonjeni su svrdlom Gates Glidden ${ }^{\text {TM }}$ (Dentsply Sirona, Italija) veličine 01-02-03 i umetnuta je kompozitna nadogradnja ojačana staklenim vlaknima srednje veličine Anatomical Post (DENTALICA, Italija) koja je fiksirana samoadhezivnim cementom (GCem LinkAce ${ }^{\text {TM }}$ proziran, GC Corp, Tokio, Japan). Trajna kompozitna restauracija izrađena je od materijala Gaenial Posterior ${ }^{\text {TM }}$ (GC Corp, Tokio, Japan) u boji A3 i odgovarajućim samojetkajućim adhezivom (Gaenial Bond $\left.{ }^{\mathrm{TM}}\right)$.

Nakon nadogradnje zub je prepariran tehnikom BOPT te je izrađena privremena krunica od PMMA-e na temelju optičkog skena snimljenog prije preparacije skenerom AADVA IOS100 (GC Corp, Tokyo, Japan). Tijekom te faze promijenjene su stare restauracije na zubima 24 i 26 (slike 4. i 5.) $(10,11)$.

Nakon dodatna četiri tjedna dorađen je nosač i uzet je konačni otisak u polivinilsiloksanskom eteru (PVS-E, Exa'Lence $^{\text {TM }}$, GC Corp., Tokio, Japan) (slika 6.). Otisak je poslan u laboratorij gdje je optički skeniran i prenesen u CAD-CAM jedinicu. 

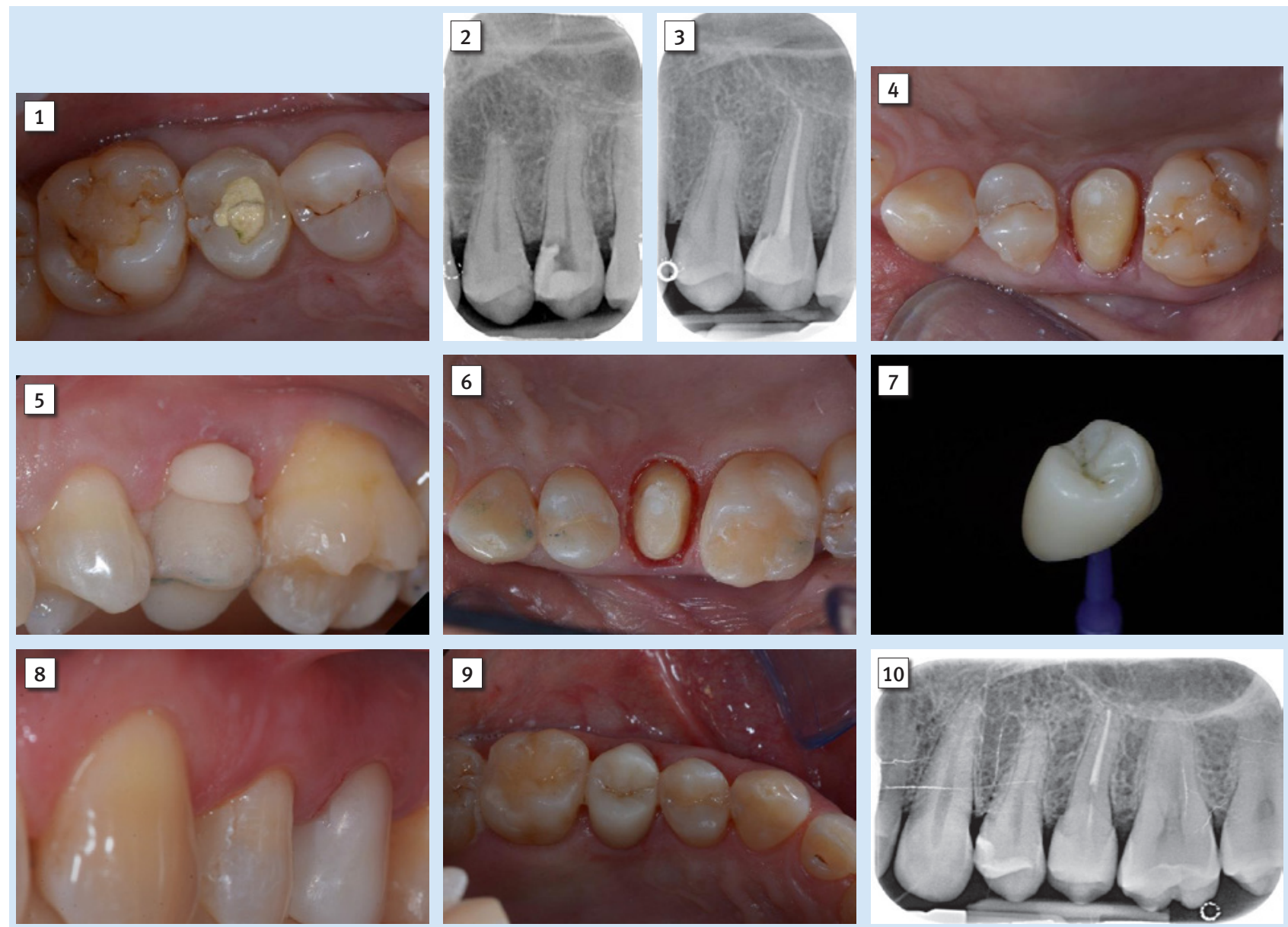

Figure 1 Initial situation. The patient reports a generic pain in the second quadrant, where there is a restoration in temporary material on tooth number 25.

Slika 1. Početna situacija - pacijentica se žalila na bol u drugom kvadrantu gdje postoji privremeni ispun na zubu 25

Figure 2 Initial radiograph showing the presence of an endodontic dressing present for several months, but the treatment has never been completed. Note the depth of the carious lesion and the proximity of the interdental bone ridge, which may represent an obstacle to prosthetic rehabilitation.

Slika 2. Početna rendgenska snimka pokazuje endodontsko liječenje koje je počelo prije nekoliko mjeseci, ali nikad nije završeno; treba obratiti pozornost na dubinu karijesne lezije i blizinu interdentalnog koštanog grebena, što može biti prepreka za protetičku rehabilitaciju

Figure 3 Radiograph of completed root canal therapy and reconstruction made completely in glass ionomer cement.

Slika 3. Rendgenska snimka nakon dovršene terapije i ispuna od stakleno-ionomernog cementa

Figure 4 Prosthetic preparation of dental element with BOPT technique. Note the minimal aggressiveness in the dental groove, recently traumatized by surgery.

Slika 4. Protetička preparacija zuba tehnikom BOPT; obratiti pozornost na minimalnu agresivnost unutar sulkusa koji je nedavno traumatiziran operacijom

Figure 5 First relining in acrylic resin of the provisional crown in PMMA obtained by digital scanning of the arches, suitable to condition the tissues after only 4 weeks from the surgery, taking advantage of the reparative thrust that follows a periodontal surgery.

Slika 5. Prvo podlaganje privremene krunice od PMMA-e dobivene digitalnim skeniranjem lukova akrilatnom smolom, čime se kondicionira tkivo samo četiri tjedna poslije operacije, koristeći se prednostima reparacijskog potencijala koji slijedi nakon parodontno-kirurškog zahvata

Figure 6 Final preparation of the tooth with the aim of taking the definitive impression. Note the total absence of bleeding despite having extended the preparation margins more apically than the first provisional

Slika 6. Završna preparacija zuba sa svrhom uzimanja konačnog otiska; obratiti pozornost na potpunu odsutnost krvarenja, iako je rub preparacije pomaknut apikalno u odnosu prema prvoj privremenoj krunici

Figure 7 The lithium-disilicate crown after polishing and fissure staining.

Slika 7. Litijeva disilikatna krunica nakon poliranja i bojenja fisura

Figure 8 Final image after polymerization and removal of composite cement excesses. Note the excellent integration of the prosthetic margins.

Slika 8. Završna slika nakon polimerizacije i uklanjanja viška kompozitnog cementa; obratiti pozornost na izvrsnu integraciju protetičkih rubova

Figure 9 Final occlusal view.

Slika 9. Završni okluzalni prikaz

Figure 10 Final radiograph of the restoration in its position, which detects an excellent integration of the margins and the respect of the biological width

Slika 10. Završna rendgenska snimka koja otkriva izvrsnu integraciju rubova i sjajnu biološku širinu 
pression was sent to the laboratory, where it has been optically scanned and a CAD-CAM path was set.

As a consequence of the new surgically modified prosthetic margin, the appropriate length of the abutment for an adhesive cementation has been obtained, and the highly esthetic requirement and the contemporary need of covering costs with a monolithic crown, led to the clinical choice of lithium-disilicate crown with high translucency, which is suitable for the CAD-CAM technology.

The chosen material was a lithium disilicate block (GC Corp, Tokyo, Japan), with an ultra-thin structure and two important advantages: first of all, the selected block was made for chairside use and it was easy to be milled, and secondly this kind of materials do not require other steps in the oven to be sintered or glazed. In fact, the selected block is in the group of those completely crystalized, hence the time for its crystallization could be saved and the software for the finishing and glazing did not have to compensate any material contraction due to the temperature in the crystallizing oven. ${ }^{17}$

In this way, the margins remain extremely thin and clear and it was particularly useful in our case. Also, it was possible to reduce costs compared to the use of a high esthetic and functional material.

Additionally, the ultra-thin structure of selected lithium disilicate blocks permits an easily polishing of the restoration even after the occlusal adjustments, leaving the area extremely uniform and smooth. This reduces the finishing times, the brightness lasts longer and the occlusal contacts produce less abrasion on the restoration and on the antagonists (Figure 7).

Regarding the luting phase, the tooth abutment was etched with 37\% orthophosphoric acid for 40 seconds, rinsed and then dried with compressed air. The definitive crown was etched with 9\% hydrofluoric acid for 40 seconds, rinsed and dried with compressed air. Since the acid etching with the hydrofluoric acid may result in the formation of crystals of lithium salts on the inner surface of the crown ${ }^{18}$, it is important to put the crown in hot water for 1 minute after the acid removal, to eliminate the crystals and prevent any interference with the adhesive cementation, and then it must be carefully dried. Before the placement of the adhesive cement, a specific coupling agent was placed in the internal face of the crown in order to obtain a stronger adherence between the ceramic and the luting resin. For this reason the G-Multi Primer (GC Corp, Tokyo, Japan) was selected and applied. The luting phase was finally performed with the G-CEM LinkForce $^{\mathrm{TM}}$ (GC Corp, Tokyo, Japan), after the placement of the dedicated adhesive system (G-Premio Bond ${ }^{\mathrm{TM}}$ ) on the adhesive surfaces of tooth and crown, blowing them with compressed air for 20 seconds, without curing them before the luting phase in order to allow the correct fitting of the crown. 40 seconds of curing time for each crown surface have been executed (120" in total in order to correctly cure both adhesive and resin cement even through the ceramic) and the excess of the luting material have been finally removed.

\section{Final results}

At the end of the procedures, the restoration was precisely set at the level of the gingival margins. It appeared to be mor-
S obzirom na novi kirurški prilagođen protetički rub, dobivena je odgovarajuća površina nosača za adhezivno cementiranje, a visoki estetski zahtjevi i potreba za smanjivanjem troškova naveli su liječnike da izaberu monolitnu krunicu od litijeva disilikata visokog stupnja translucencije pogodnog za CAD-CAM tehnologiju.

Odabrani litijev disilikatni blok (GC Corp, Tokio, Japan) ima ultratanku strukturu i dvije važne prednosti - prva je da je odabrani blok pripremljen za uporabu u ordinaciji i lako se obrađuje, a druga, ta vrsta materijala ne zahtijeva sinteriranje ili glaziranje u peći. Zapravo je odabrani blok iz skupine materijala koji su potpuno kristalizirani, tako da se može uštedjeti vrijeme za njegovu kristalizaciju, a softver za završnu obradu i glaziranje ne mora kompenzirati kontrakciju materijala zbog temperature u peći za kristalizaciju ${ }^{17}$.

$\mathrm{Na}$ taj način rubovi ostaju iznimno tanki i jasni te su u ovom slučaju posebno korisni, a također je moguće smanjiti troškove u usporedbi s upotrebom drugih visokoestetskih i funkcionalnih materijala.

Uz to, ultratanka struktura odabranih litijevih disilikatnih blokova omogućuje jednostavno poliranje restauracije, čak i nakon okluzalnog ubrušavanja, ostavljajući površinu iznimno ujednačenom i glatkom. To skraćuje završnu obra$\mathrm{du}$, svjetlina traje dulje i okluzalni kontakti uzrokuju manje abrazije na restauraciji i antagonistima (slika 7.).

Prije cementiranja nosač je 40 sekunda jetkan 37-postotnom ortofosfornom kiselinom, ispran i osušen komprimiranim zrakom. Krunica je jetkana 9-postotnom fluorovodičnom kiselinom 40 sekunda, isprana i osušena komprimiranim zrakom. Budući da jetkanje fluorovodičnom kiselinom može rezultirati stvaranjem kristala litijevih soli na unutarnjoj površini krunice ${ }^{18}$, važno ju je staviti u vruću vodu jednu minutu nakon ispiranja kiseline kako bi se uklonili kristali i spriječilo ometanje adhezivne veze, a zatim se mora pažljivo osušiti. Prije stavljanja adhezivnog cementa, unutarnja površina krunice premazuje se posebnim veznim sredstvom kako bi se postiglo jače prianjanje između keramike i kompozitnog cementa. Za to je odabran G-Multi Primer (GC Corp, Tokio, Japan). Za cementiranje je korišten G-CEM LinkFor$\mathrm{ce}^{\mathrm{TM}}$ (GC Corp, Tokio, Japan), nakon aplikacije namjenskog adhezivnog sustava (G-Premio Bond ${ }^{\mathrm{Tm}}$ ) na vezne površine zuba i krune i te ispuhivanja komprimiranim zrakom 20 minuta, bez polimerizacije kako bi se omogućilo pravilno sjedanje krunice. Nakon namještanja krunice obavljena je svjetlosna polimerizacija i to 40 sekunda za svaku površinu (ukupno 120 sekunda kako bi se polimerizirali adheziv i cement, čak i kroz keramiku), a višak materijala je uklonjen.

\section{Konačni rezultat}

$\mathrm{Na}$ kraju postupaka restauracija je točno sjedila na razini gingivnih rubova $\mathrm{i}$ činilo se da je morfološki integrirana 
phologically integrated in the dental arch, with correct contact points and with a good chromatic match with the adjacent elements (Figures 8-9). If we look at the $\mathrm{x}$-ray image, it is possible to see that the sub-gingival margins are also integrated, without any step or any plaque-retaining area that could be a problem for the home dental hygiene (Figure 10). The patient did not report any pain and was completely satisfied with the prosthetic rehabilitation. She stated that the restoration was perfectly integrated at both functional and chromatic levels. She also believed that the color of the prosthesis was better than the color of her natural teeth. Also, she has requested information about tooth whitening.

\section{Discussion}

This case presents a very frequent case that dentists face during their practice. Due to their position and function, premolars are often affected by tooth decay; hence there is a need for endodontic treatments, posts and even extensive restorations. In this case report, the dentist had to primarily solve pain, consequent to an incomplete endodontic treatment, but then to guarantee enough solidity to whatever is the planned, final rehabilitation. CAD-CAM technology and chairside procedures, including the milling process that takes place completely inside the dental clinic, are actually a valuable reality and these kinds of digital machines have been easily available for many years $(12,17,19)$.

In this specific case, the choice has been directed towards a lithium-disilicate ceramic block for the manufacturing of both an esthetic and durable crown. The lithium-disilicate is in fact an ideal material for restorations in molars and premolars, having a very high flexural strength and compressive resistance, but preserving highly esthetic properties, such as translucency, proper light reflection, natural opacity and fluorescence. Even the choice of a monolithic material such as presented in our case is a clear example of how these categories of new millable materials can fit even if there is a demand for esthetic results.

The required time for the complete crown fabrication inside the dental clinic, from designing, milling to finishing, may vary depending on the material: the required fabrication time ranges normally from 1 hour (for the simplest materials) to more than 4 hours (for the materials that after milling require more tests and passages in finishing furnaces. For this reason, and due to the diffusion of CAD-CAM procedures in laboratories, chairside procedures are actually less appreciated by many dentists, who see them as a possible waste of time, diverting them from the real clinical activity ${ }^{12}$. However, the reliability of modern CAD-CAM systems and new materials allow dentists and laboratories to make new choices, even in the name of a smoother workflow and cost control, when possible. A millable material that has considerable esthetic properties is in any case indispensable, whether a clinician decides for a full chairside procedure, or for sending the impression in the laboratory. Also the "monolithic" materials cannot actually afford to be opaque, not very natural and not very translucent, because very few professionals and patients are inclined to accept esthetic compromises in modern times u zubni luk, $s$ ispravnim kontaktnim točkama i dobrom podudarnošću boje sa susjednim zubima (slike 8. i 9.). $\mathrm{Na}$ rendgenskoj snimci može se vidjeti da su i rubovi ispod gingive integrirani, bez stepenice ili prostora za zadržavanje plaka koji bi mogli biti problem tijekom održavanja higijene kod kuće (slika 10.). Pacijentica se više ne žali na bolove i zadovoljna je protetičkom rehabilitacijom za koju smatra da se savršeno integrirala i s funkcionalnog i s estetskog stajališta. Također vjeruje da je boja krunice ljepša od prirodnih zuba te se raspitivala o izbjeljivanju.

\section{Rasprava}

Ovo je slučaj s kakvim se kliničari često moraju suočiti u praksi. Zbog položaja i funkcije, pretkutnjaci su često podložni velikim oštećenjima i moraju se endodontski liječiti, a potrebne su i nadogradnje te velike restauracije. U ovom slučaju kliničar je najprije morao ukloniti bol, što je posljedica nepotpunoga endodontskog liječenja, a zatim osigurati dovoljnu čvrstoću nosača za sve što je planirano. CAD-CAM tehnologija i postupci u ordinaciji, uključujući i glodanje nadomjestka, danas su stvarnost i takvi su digitalni uređaji lako dostupni već godinama $(12,17,19)$.

U ovom specifičnom slučaju izbor je pao na litijev disilikatni keramički blok za izradu estetske i trajne krunice. Litijev disilikat zapravo je idealan materijal za restauraciju kutnjaka i pretkutnjaka jer su njegova savojna i tlačna čvrstoća vrlo visoke, a ima i odlična estetska svojstva kao što su translucencija, refleksija svjetla, prirodna neprozirnost i fluorescencija. Čak i u obliku monolitnog nadomjestka, kao u prikazanom slučaju, novi materijali mogu se savršeno uklopiti bez obzira na veće estetske zahtjeve.

Potrebno vrijeme za kompletnu izradu krunice u ordinaciji - od oblikovanja i glodanja do završne obrade - može varirati ovisno o materijalu: vrijeme potrebno za proizvodnju u pravilu je od jednog sata (za najjednostavnije materijale) do više od četiri sata (za materijale koji nakon glodanja zahtijevaju cikluse pečenja). Zbog toga, i zbog uobičajene procedure uključivanja laboratorija u proizvodnju, mnogi kliničari smatraju da je proizvodnja u ordinaciji gubitak vremena i manje cijene takav postupak jer su mišljenja da doktora odvraća od njegovih stvarnih zadaća ${ }^{12}$. No pouzdanost suvremenih CAD-CAM sustava i novih materijala omogućuje kliničarima i laboratorijima da donesu novu odluku kako bi osigurali nesmetani rad i kontrolu troškova kad god je to moguće. Materijal za glodanje s dobrim estetskim svojstvima u svakom je slučaju prijeko potreban, bilo da se terapeut odluči za postupak koji se u cijelosti obavlja u ordinaciji, bilo da šalje otisak u laboratorij. Istaknimo da monolitni materijali zapravo ne mogu biti potpuno neprozirni, što nije nimalo prirodno jer je danas vrlo malo kliničara i pacijenata spremno prihvatiti estetske kompromise (20,21). Sa stajališta kliničara, postupci poliranja nakon mogućih okluzalnih prilagodbi ne bi trebali zahtijevati mnogo vremena, ni namjenskih instrumenata i pečenja, što bi značilo dodatne troškove za kliniku i manje vremena za kliničke aktivnosti. 
$(20,21)$. Moreover, from the dentist's point of view, polishing procedures after possible occlusal adjustments should not require much time and special instruments and burs, which means smaller expenses for the clinic and more time to dedicate to dental activities.

The patient in this case report represents a stereotype of a highly demanding patient. This normally does not mean that she necessarily needs perfect esthetics, but the resolution of the initial problems (spontaneous pain, also stimulated on chewing, trapping of food in proximal areas, marginal inflammation) is mandatory to achieve the success. Endodontic treatment is the main part of the rehabilitation, because only an appropriate endodontic therapy can solve the pain and permit a solid restoration. However, the position of the restoration, very close to the marginal crest, and the need of performing adhesion for the luting of both composite and ceramic, suggest to clinician to carefully evaluate all the possible complications during the prosthetic procedures, since the wrong positioning of the crown margins could lead to chronical inflammation, bone resorption, pain and definitely to tooth loss. The choice of performing a surgical procedure such as the crown lengthening is a simple, strategical step that normally allows creating in a single appointment all the ideal conditions that a complex tooth such as an upper premolar is not offering after extensive tooth decay. In this case, the dentist must respect all ideal healing times, in order to allow the periodontal ligament to recreate a physiologic architecture that normally occurs after at least 21 days of healing process. For this reason, after the surgery but also after the initial preparation for the provisional crown, the authors of this case report decided to wait for 4 weeks (28 days).

The choice of the BOPT technique has been identified as the ideal one for this specific case. First, the mesial carious lesion is close to the bone crest, but also involving the root (Figure 2). In that area, a shoulder preparation requires a huge waste of tooth structure in respect to a vertical preparation. Even in the case the crown lengthening, this sacrifice of sound tissue cannot be limited. A vertical preparation on the other side can be limited to the surface areas, with minimal sacrifice of root tissues, and a good control during luting procedures. Even a margin relocation using a glassionomer can be considered in this case, but the depth of the lesion and good control after crown lengthening suggested to put directly the crown margin on the sound tissue of the root. The $\mathrm{CAD}$ design in case of a vertical preparation of teeth normally requires higher skills from the technician, since good fitting and lack of steps, notches and/or marginal chippings are fundamental for the biological integration of the crown under the gingival margin.

\section{Conclusions}

Monolithic, CAD-CAM solutions appear to be a reliable solution for prosthetic rehabilitations even in sectors where esthetics, translucency and reflection of natural light might be of primary importance for patient satisfaction. However, the choice of ideal properties of the selected material still remains of fundamental importance. An ideal monolithic ma-
Pacijentica je u ovom slučaju stereotip vrlo zahtjevnog pacijenta. To obično ne znači da joj nužno treba savršena estetika, ali je za uspjeh potrebno rješavanje početnih problema (spontana bol također potaknuta žvakanjem, upadanje hrane u aproksimalna područja, marginalna upala). Endodontsko liječenje je, naravno, glavni dio rehabilitacije jer samo odgovarajuća terapija može anulirati bol i omogućiti stabilnu restauraciju. No položaj nadomjestka vrlo blizu rubnog grebena i potreba za postizanjem adhezije za vezanje kompozita i keramike, sugeriraju kliničaru da pozorno procijeni sve moguće komplikacije tijekom protetičkih postupaka jer bi pogrešno pozicioniranje ruba krunice moglo rezultirati kroničnom upalom, resorpcijom kosti, bolovima i definitivnim gubitkom zuba. Izbor kirurškoga zahvata, poput produljenja kliničke krune, jednostavan je strateški potez koji obično u jednom posjetu omogućuje stvaranje svih idealnih uvjeta na izrazito destruiranom zubu poput gornjeg pretkutnjaka u ovom slučaju. Važno je poštovati vrijeme potrebno za idealno cijeljenje kako bi se omogućilo da parodontni ligament stvori fiziološku arhitekturu, što se obično događa nakon najmanje tri tjedna. Iz tog razloga, nakon operacije, ali i nakon početne preparacije za privremenu krunicu, liječnici su u ovom slučaju odlučili čekati četiri tjedna (28 dana).

Izbor BOPT tehnike smatra se idealnim za ovaj slučaj. Kao najvažnije, mezijalna karijesna lezija nalazila se blizu koštanog grebena, ali zahvaćala je i korijen (slika 2.). U tom području stepenična preparacija zahtijeva golem gubitak zubnog tkiva u odnosu prema tangencijalnoj preparaciji. Čak i u slučaju produljenja kliničke krune, to žrtvovanje zdravoga tkiva ne može se ograničiti. Tangencijalna preparacija, $s$ druge strane, zahtijeva minimalno žrtvovanje tkiva i osigurava dobru kontrolu tijekom postupaka cementiranja. Čak i premještanje ruba stakleno-ionomernim cementom može se uzeti u obzir u ovom slučaju, ali dubina lezije i dobra kontrola nakon produljenja kliničke krune naložili su izravno pozicioniranje ruba krunice na zdravo tkivo korijena. CAD dizajn u slučaju tangencijalne preparacije obično zahtijeva veću vještinu tehničara jer je dobar dosjed bez stepenica, ureza i/ili rubnih odlamanja temelj za biološku integraciju krunice pod rubom gingive.

\section{Zaključci}

Monolitna CAD-CAM rješenja čine se kao pouzdano rješenje za protetičku rehabilitaciju, čak i u područjima u kojima bi estetika, translucencija i refleksija prirodne svjetlosti mogle biti primarno važne za pacijentovo zadovoljstvo. No izbor materijala idealnih svojstava za određeni slučaj i dalje ostaje najvažniji. Idealan monolitni materijal mora ima- 
terial must have the following characteristics, which a dentist must know in order to make an appropriate choice for esthetic and functional rehabilitations: Availability of different shades; Adequate translucency; Ease of processing and milling (little wear on milling burs and machinery); High mechanical strength; Durable in physiologic and pathological oral environment $(16,19)$. Possibility of simple luting with most common adhesive systems or cements; Quick intraoral polishing phase; Availability for the most common chairside and laboratory milling machines (compatibility).

Only a good mix of these characteristics can determine a clinical success of a prosthetic rehabilitation procedure with monolithic materials and, ultimately, full patient satisfaction. ti sljedeće karakteristike koje kliničar mora poznavati kako bi mogao ispravno odlučiti o estetskoj i funkcionalnoj rehabilitaciji: dostupnost različitih boja, adekvatnu translucenciju, jednostavnost obrade i glodanja (rijetku upotrebu svrdala i strojeva), veliku čvrstoću, izdržljivost u fiziološkom i patološkom oralnom okružju $(16,19)$, mogućnost jednostavnog cementiranja uobičajenim adhezivnim sustavima i cementima, jednostavno poliranje u ustima, kompatibilnost $s$ najzastupljenijim ordinacijskim i laboratorijskim glodalicama.

Samo dobar spoj svih tih značajki može osigurati klinički uspjeh protetičke rehabilitacije monolitnim nadomjestcima $\mathrm{i}$, u konačnici, potpuno zadovoljstvo pacijenta.

\section{Sažetak}

Cilj: Restaurativno liječenje destruiranog avitalnog gornjeg pretkutnjaka često zahtijeva interdisciplinarni pristup. Na izbor postupaka i materijala obično utječu estetski zahtjevi i žvačno opterećenje. U ovom prikazu opisuje se konzervativno liječenje u skladu s estetskim potrebama i funkcionalnim zahtjevima. Materijali i metode: Opisan je slučaj žene u dobi od 45 godina s vrlo destruiranim gornjim pretkutnjakom. Zub je ranije bio hitno provizorno endodontski liječen. U trenutku posjeta bio bolan i činilo se da se karijesna lezija proteže subgingivno. Odabran je kirurško-konzervativni pristup koji je uključivao produljenje kliničke krune, endodontsko liječenje i protetičku terapiju krunicom od monolitnog litijeva disilikata. Rezultati: Proces rehabilitacije trajao je tri mjeseca, uključujući i vrijeme cijeljenja nakon operacije te postavljanje privremene krunice. Pacijentica je opskrbljena estetski i funkcionalno. Zaključak: Konzervativno liječenje teško oštećenog zuba zahtijeva kritičku procjenu preostalih struktura i pažljiv odabir restaurativnog materijala. Monolitna krunica mogla bi biti idealno rješenje za restauraciju gornjeg pretkutnjaka koji treba ispuniti estetske i funkcijske zahtjeve. Izbor visoko translucentnog materijala koji se lako polira i uz to može obrađivati u ordinaciji, kliničarima pruža dodanu vrijednost.
Zaprimljen: 30. kolovoza 2019.

Prihvaćen: 1. prosinca 2019.

Adresa za dopisivanje

Matteo Basso

University of Milan

Dental clinic

CROMED

Milan, Italy

clinic@matteobasso.it

Ključne riječi

pretkutnjak; produljenje krune zuba; krunice

\section{References}

1. Setzer FC and Kim S. Comparison of Long-term Survival of Implants and Endodontically Treated Teeth. J Dent Res. 2014 Jan;93(1):19-26.

2. Ruskin JD, Morton D, Karayazgan B, Amir J. Failed root canals: the case for extraction and immediate implant placement. J Oral Maxillofac Surg. 2005 Jun;63(6):829-31.

3. Lundgren D, Rylander H, Laurell L. To save or extract, that is the question. Natural teeth or dental implants in periodontitis-susceptible patients: clinical decision-making and treatment strategies exemplified with patient case presentations. Periodontol 2000. 2008;47:27-50.

4. Lanning SK, Waldrop TC, Gunsolley JC, Maynard JG. Surgical crown lengthening: evaluation of the biological width. J Periodontol. 2003 Apr;74(4):468-74.

5. Allen EP. Surgical crown lengthening for function and estheticsDent Clin North Am. 1993 Apr;37(2):163-79.

6. Ong M, Tseng $\mathrm{S}$, Wang $\mathrm{H}$. Crown lengthening revisited. Clin Adv Periodontics 2011;1(3):233-239.

7. Khaled Al-Omiri M, Mahmoud AA, Rayyan MR, Abu-Hammad O. Fracture resistance of teeth restored with post-retained restorations: An overview. J Endod. 2010 Sep;36(9):1439-49.

8. Barcellos RR, Correia DP, Farina AP, Mesquita MF, Ferraz CC, Cecchin $\mathrm{D}$, et al. Fracture resistance of endodontically treated teeth restored with intra-radicular post: the effects of post system and dentine thickness. J Biomech. 2013 Oct 18;46(15):2572-7.

9. Devčić N, Miletić I, Pezelj-Ribarić S, Šegović S. Microleakage of Different Root Canal Obturation Techniques. Acta Stomatol Croat. $2005 ; 39(1): 77-84$

10. Loi I, Di Felice A. Biologically oriented preparation technique (BOPT): a new approach for prosthetic restoration of periodontically healthy teeth. Eur J Esthet Dent. 2013 Spring;8(1):10-23.

11. Serra-Pastor B, Loi I, Fons-Font A, Solá-Ruíz MF, Agustín-Panadero R. Periodontal and prosthetic outcomes on teeth prepared with biologically oriented preparation technique: a 4-year fol- low-up prospective clinical study. J Prosthodont Res. 2019 Oct;63(4):415-420.

12. Basso M, Nowakowska J.K, Del Fabbro M. Long-term Dental Restorations using high-viscosity Coated Glass ionomer Cements. Abstract 2494-IADR 2011, San Diego, USA

13. Lohbauer U, Krämer N, Siedschlag G, Schubert EW, Lauerer B, Müller FA, et al. Strength and wear resistance of a dental glassionomer cement with a novel nanofilled resin coating. Am J Dent. 2011 Apr;24(2):124-8.

14. Hedzelek W, Muszalski B, Joniak S. Comparison of Tearing off and Impact Load Resistance of Selected Phosphate and Glassionomer Cements. Acta Stomatol Croat. 2002;36(3):352.

15. Türkün LS, Kanik Ö. A Prospective Six-Year Clinical Study Evaluating Reinforced Glass lonomer Cements with Resin Coating on Posterior Teeth: Quo Vadis? Oper Dent. 2016 Nov/Dec;41(6):587598.

16. Basso M, Brambilla E, Benites MG, Giovannardi M, Ionescu AC. Glassionomer cement for permanent dental restorations: a 48-months, multi-centre, prospective clinical trial. Stoma Edu J. 2015;2(1):25-35.

17. Rotgans J. Ceramic Reconstruction (CEREC) - an Ingenious Concept in Restorative Dentistry? Acta Stomatol Croat. 2002;36(3):311.

18. Hesse D, Bonifácio CC, Bönecker M, Guglielmi Cde A, da Franca C, van Amerongen WE, et al. Survival Rate of Atraumatic Restorative Treatment (ART) Restorations Using a Glass Ionomer Bilayer Technique with a Nanofilled Coating: A Bi-center Randomized Clinical Pediatr Dent. 2016 Jan-Feb;38(1):18-24.

19. Jakovac M, Živko-Babić J, Ćurković L, Carek A. Chemical Durability of Dental Ceramic Material in Acid Medium. Acta Stomatol Croat. 2006;40(1):65-71.

20. Viskić J, Ortolan SM, Gašparić LB, Mehulić K. Application of lithium-disilicate ceramics in the aesthetic restoration of frontal teeth. Acta Somatol Croat. 2013;47 (4):361-361.

21. Arvind Shenoy, Nina Shenoy. Dental Ceramics: an update. J Conserv Dent. 2010 Oct-Dec;13(4):195-203. 